\title{
Hane Halkının Finans Eğitimi ve Finansal Okuryazarlık Düzeyleri Üzerine Kocaeli’nde Bir Araştırma
}

\author{
Sibel FETTAHOĞLU*
}

\section{ÖZET}

Finansal okuryazarlık, temel düzeyde finansal ürünler ve uygulamalar hakkında bilgi sahibi olarak karar alabilme becerisidir. Sadece birey/ hane halkı açısından değil aynı zamanda sermaye piyasalarının gelişmesi açısından da finansal okuryazarlık önemlidir. Sermaye piyasalarının gelişebilmesi için yatırımcı tabanının genişletilmesi gerekir. Bunu gerçekleştirebilmek için finans eğitimi çalışmaları önem kazanmaktadır.

Bu çalışmanın amaçlarından birincisi, ankete katılan örneklem kitlenin finansal okuryazarlı düzeylerinin belirlenmesi, ikincisi ise hane halkının aile bütçesinin yönetimi konusunda bilgi ve davranışlarını belirlemeye çalışmaktır. Kocaeli'nde ikamet eden tesadüfi örnekleme yöntemine göre seçilmiş 83 katılımcının anket formu değerlendirilmiştir. Elde edilen veriler ANOVA ile analiz edilmiştir. Analiz sonucunda finansal okuryazarlik konusunda katılımclların temel düzeyde bilgilerinin olduğu ancak karmaşık ve bilgiyi gerektiren araç, ürün ve teknikler konusunda yetersizliklerin olduğu belirlenmiştir. Aynı zamanda hane halkı açısından yatırım araçlarını tanıma ve yatırım yapma konusunda bilgi eksikliği olduğu hisse senedi, tahvil, yatırım fonu gibi menkul değerlerin kullanımının düşük olduğu belirlenmiştir.

Anahtar Kelimeler: Hane Halkl, Finans Eğitimi, Finansal Okuryazarlık, Kocaeli.

JEL Sinıflandirmasi: D14, I22. \section{Kocaeli \\ A Study of Financial Education and Financial Literacy Level about Households in}

\section{ABSTRACT}

Financial literacy is basically a skill for making decisions about financial products and their applications. It is not only important for individuals / households also it is important for developing capital markets. If capital markets wanted to be developed, investor floor should be improved. Thus, financial education practices are important in this stage. The first aim of the study is to determine financial literacy level of the participants in the survey and the second aim of the study is to determine household's attitudes and knowledge levels about managing their house budgets. The survey was administrated to 83 investors who lived in Kocaeli. The selection was made by random sampling. ANOVA used to test variables. The results of the analysis shows that participants do have knowledge of basic economic and financial concepts but their financial literacy about complex financial products and techniques are unsatisfactory for this study. Besides that households do not make enough investment especially in bond, stock and funds.

Keywords: Household, Financial Education, Financial Literacy, Kocaeli.

Jel Classification: D14, I22.

\footnotetext{
*Doç. Dr. Sibel FETTAHOĞLU, Kocaeli Üniversitesi, İktisadi ve İdari Bilimler Fakültesi, İşletme Bölümü, stopdemir@kocaeli.edu.tr
} 


\section{GíRiş̧}

Finansal okuryazarlık, finansal ürün ve uygulamalar ile ilgili temel düzeyde bilgi sahibi olmak ve bu bilgiyi finansal kararların alınmasında kullanabilme yeteneği olarak tanımlanmaktadır (Temizel ve Bayram, 2011: 75). Finansal okuryazarlık bireylerin günlük hayatta karşılaş̧ıkları finansal sorunların çözümüne katkı sağlarken finansal piyasaların da etkin ve verimli çalışmasını sağlar. Mason ve Wilson (2000: 5), finansal okuryazarlığı, bir bireyin finansal kavramların farkında olarak, karar vermede gerekli olan bilgileri elde etme, anlama ve değerlendirmesi olarak tanımlamaktadır. Finansal okuryazarlık bu bağlamda içine bilgi kaynakları, bu bilgiyi sağlayacak teknoloji ve olanakları kullanma becerisini de katan bir süreç olarak düşünülebilir. Amerika Birleşik Devletleri (ABD) Başkanı'nın Finansal Okuryazarlık Konusunda Danışma Konseyi (President's Advisory Council on Finansal Literacy) tarafından 2008 yılında hazırlanan raporda finansal okuryazarlık, bireylerin yaşamı boyunca finansal güvenliği için, finansal kaynaklarını etkin bir biçimde kullanabilmesi ve bunu sağlayabilecek bilgiyi kullanabilme yeteneği olarak tanımlanmıştır. Lusardi (2008: 2)'ye göre bireyler, temel düzeyde finansal kavramları anlamak, basit ekonomik hesaplamaları yapabilmek, finans bütçesini yönetebilmek zorundadır. Bu zorunluluk özellikle düşük eğitim grupları ve kadınlar açısından önemlidir. Bu bağlamda finansal okuryazarlık bireylerin sermaye piyasasına katılımından bireysel emeklilik planlarına kadar finansal kararlarını vermede etkili olmaktadır. Lusardi (2008: 4), finansal okuryazarlığ 1 temel ve gelişmiş düzeyde finansal okuryazarlık olarak iki düzeyde sınıflandırmıştır. Faiz oranları hakkında yorum yapabilme, enflasyonun etkilerini, risk kavramını ve çeşitliliğini algılayabilme temel düzey olarak kabul edilirken hisse senedi piyasası, fonlar, bono fiyatları ve faiz oranları ile ilgili hesaplamaları gelişmiş okuryazarlık kapsamında değerlendirilmiştir.

Finansal okuryazarlık sadece bireyler açısından değil ülke ekonomisi açısından da önemlidir. Sermaye piyasaları aracıllğıyla ufak birikimler büyük tutarlara dönüşerek yatırımlar gerçekleştirilir. Finansal tabana yayılmanın talep yönünü finansal okuryazarlık oluştururken, arz yönünü ise finansal erişim oluşturmaktadır. Türk Sermaye Piyasası'nın istenen gelişmişlik düzeyine ulaşması için yatırımcı tabanının güçlendirilmesi gerekmektedir. Bunu sağlamanın yollarından biri de sermaye piyasaları hakkında farkındalık yaratmak ve tasarruf sahiplerini bilgilendirme yoluyla finans piyasalarına girişin tabana yayılmasıdır. $\mathrm{Bu}$ bağlamda Dünya Bankası tarafindan Hazine müsteşarlı̆ı̆, Bankacılık Düzenleme ve Denetleme Kurulu (BDDK), Sermaye Piyasası Kurulu (SPK) ve Borsa İstanbul (BIST) işbirliği ile "Türkiye Finansal Tabana Yayılma" Konferansı 3-4 Haziran 2014 tarihinde İstanbul' da gerçekleştirilmiştir.

Finansal okuryazarlık arttıkça bireyler daha fazla bilgi talep edeceğinden piyasada şeffaflık artacaktır. Bir toplumda tasarruf yapma alışkanlığını bireylere kazandırmaya yönelik eğitimlerin olmayışı, o ülke açısından finansal piyasaların yeterince gelişmemesine neden olur. Türkiye'de finansal sistemin dışında kalan yetişkinlerin oranı \%51 iken bu oran Hollanda'da \%0, Almanya'da \%3 ve İngiltere'de \%9'dur. Dolayısıyla ekonomik büyüme için 
sistem dışındaki fonlar sisteme kazandırılmalıdır (T.C. Merkez Bankası, 2011: 1). Türk Ekonomi Bankası'nın yapmış olduğu Finansal Okuryazarlık Endeksi Türkiye geneli için 59.8 olarak hesaplanmıştır. Atkinson ve Messy(2012: 40-43 )'nin yaptıkları çalışmada diğer ülkelerin ortalama puanı ise 62.3'tür. Bu bağlamda Türkiye açısından finansal okuryazarlık ve finansal eğitim alanlında toplumda farkındalık yaratmanın gerekliliği ortaya çıkmaktadır.

OECD (2005: 26)'ye göre finansal eğitim, bireylerin finansal ürün ve kavramları anlaması, finansal riskten kaçınma ve finansal firsatlardan yararlanma yeteneğini geliştirmeye yönelik bir süreçtir. Küreselleşmeyle birlikte finansal piyasaların bütünleşmesi, karmaşıklaşması ve finansal yeniklerin artması bireylerin alacakları finansal kararlarda daha fazla bilgiye gereksinim duymasına yol açmaktadır. Bu bağlamda toplumda finansal okuryazarlığın artırılmasında sadece üniversiteler ve eğitim kurumlarına değil, medya ve sivil toplum kuruluşlarına da önemli görevler düşmektedir. Kredi kartı kullanma, mevduat hesabı açtırma, kredi kullanma gibi işlemler bile uygulamada toplum içinde sorunlara yol açarken, yeni teknoloji ve finansal ürünler, yaşanan finansal krizler, finansal kurumlara olan güvenin azalması finansal okuryazarlığa önem verilmesini gerektirmektedir (Bayram,2010: 15). En basit şekliyle bireysel olarak alınan borçların ve aile bütçesinin yönetiminde de finansal eğitim ve finansal okuryazarlık ihtiyacı ortaya çıkmaktadır.

Finansal okuryazarlığa ilişkin literatür taraması yapıldığında Volpe, Chen ve Pavlicko (1996: 86) 454 üniversite öğrencisi üzerinde yatırım yönetimine ilişkin bilgi düzeylerini belirlemeye çalıştılar. Volpe, Kotel ve Chen (2002: 1) internet üzerinden e-finans olanaklarından yararlanarak yatırım kararı alan 530 yatırımcı üzerinde uyguladıkları anket ile katılımcıların yatırım bilgi düzeylerini ölçümlemeye çalıştılar. Hilgert, Hogarth ve Beverly (2003: 309), çalışmalarında hane halkı açısından finansal yönetim faaliyetlerini (1) Parasal akımların yönetimi, (2) Borçların yönetimi, (3) Tasarruflar ve (4) Yatırımların yönetimi olmak üzere dört grup altında sinfflandırdılar. Moore (2003: 19), Washington State Üniversitesi'nde 1423 kişi üzerinde finansal bilgi, finansal deneyim, finansal davranış ve borç yönetimi konularında finansal okuryazarlığı ölçümlemeye çalışmıştır. NCEE (2005: 4) tarafından Amerika'lı gençler üzerinde yatırım, tasarruf ve borç yönetimi konularında finansal okuryazarlık ölçümlenmeye çalışılmıştır. Türkiye'de finansal okuryazarlık üzerine yapılan çalışmalar incelendiğinde Bayram (2010: 1-70) ile Temizel ve Bayram (2011:7 3-86) Anadolu Üniversitesi öğrencileri üzerine finansal okuryazarlık araştırması yaptılar. Araz (2012: 1-118) Türkiye'nin 22 ilinde 2576 kişi üzerinde bir anket uygulayarak finansal okuryazarlık ve kredi kartı sorunları üzerine bir araştırma gerçekleştirmiştir. Özdemir (2012: 1-40) Kalkınma Bakanlı̆̆ı'nın Dünya Bankası işbirliği ile hazırladığı 10.264 kişi ve 3009 hane üzerinde finansal okuryazarlık anketi gerçekleştirmiştir. Türk Ekonomi Bankası (TEB) Boğaziçi Üniversitesi işbirliği ile "Türkiye Finansal Okuryazarlık Endeksi” hazırlanmıştır. 


\section{ANALIZ SONUÇLARI VE YORUMLAR}

$\mathrm{Bu}$ çalışmanın amaçlarından birincisi, ankete katılan örneklem kitlenin finansal okuryazarlık düzeylerinin belirlenmesi, ikincisi ise hane halkının aile bütçesinin yönetimi konusunda bilgi ve davranışlarını belirlemeye çalışmaktır. Kocaeli'nde ikamet eden ve tesadüfi örnekleme yöntemine göre seçilen kişilerden, anket formunu eksiksiz bir şekilde dolduran 83 kişinin anketi değerlendirmeye alınabilmiştir.

Tablo 1, anketi yanıtlayan katılımcılara ilişkin tanımlayıcı bilgileri içermektedir. Anketi yanıtlayanların \%49'u erkek \%51'i bayandır. Katılımcıların \%70'i evli, \%57'si lisans, yüksek lisans ve doktora mezunudur. 44 yaş altında olan katılımcıların, \%68 pay ile toplam katılımcılar içinde genç ve orta yaş düzeyinde yoğunlaştıkları görülmektedir. Hanedeki kişi sayısının en çok \%31 ile 3 kişilik çekirdek aile şeklinde olduğu görülmektedir. Buna paralel olarak ailede gelir getiren kişi sayısı \% 71 ile 2 kişi olarak belirlenmiştir. Katılımcıların \%49'unun aile geliri 1000-3000 TL arasındadır. Ailede parasal kararları \%55 gibi yüksek bir yüzdeyle eşlerin birlikte verdikleri belirlenmiştir.

Tablo 1: Anket Sorularını Yanıtlayan Katılımcılara İlişkin Tanımlayıcı Bilgiler

\begin{tabular}{|c|c|c|}
\hline Cinsiyet & Adet & $\%$ \\
\hline Erkek & 41 kişi & $\% 49$ \\
\hline Kadm & 42 kişi & $\% 51$ \\
\hline \multicolumn{3}{|l|}{ Medeni Durumu } \\
\hline Evli & 58 kişi & $\% 70$ \\
\hline Bekar & 25 kişi & $\% 30$ \\
\hline \multicolumn{3}{|l|}{ Eğitim Düzeyi } \\
\hline Okuryazar & 2 kişi & $\% 2$ \\
\hline Ilköğretim & 12 kişi & $\% 15$ \\
\hline Lise & 22 kiși & $\% 26$ \\
\hline Universite & 38 kişi & $\% 46$ \\
\hline Yüksek Lisans-Doktora & 9 kişi & $\% 11$ \\
\hline \multicolumn{3}{|l|}{ Yași } \\
\hline $18-25$ yaş arası & 15 kişi & $\% 18$ \\
\hline $26-33$ yaş arası & 22 kişi & $\% 27$ \\
\hline $34-43$ yaş aras 1 & 19 kişi & $\% 23$ \\
\hline 44-51 yaş arası & 8 kiși & $\% 9$ \\
\hline 52 yaş ve üstü & 19 kişi & $\% 23$ \\
\hline \multicolumn{3}{|l|}{ Hanedeki Kiși Sayısı } \\
\hline 1 kişi & 3 kişi & $\% 4$ \\
\hline 2 kişi & 19 kişi & $\% 23$ \\
\hline 3 kişi & 26 kişi & $\% 31$ \\
\hline 4 kişi & 20 kişi & $\% 24$ \\
\hline 4 kişiden fazla & 15 kişi & $\% 18$ \\
\hline \multicolumn{3}{|c|}{ Hanede Gelir Getiren Kiși Sayısı } \\
\hline 1 kişi & 17 kişi & $\% 21$ \\
\hline 2 kiși & 59 kişi & $\% 71$ \\
\hline 3 kişi & 2 kişi & $\% 2$ \\
\hline 4 kişi & 4 kişi & $\% 5$ \\
\hline 4 kișiden fazla & 1 kişi & $\% 1$ \\
\hline \multicolumn{3}{|l|}{ Ailenin Ayhk Geliri } \\
\hline $1000 \mathrm{TL}^{3} \mathrm{den}$ az & 3 kişi & $\% 4$ \\
\hline $1001-2000 \mathrm{TL}$ & 21 kişi & $\% 25$ \\
\hline $2001-3000 \mathrm{TL}$ & 20 kişi & $\% 24$ \\
\hline $3001-4000 \mathrm{TL}$ & 16 kişi & $\% 19$ \\
\hline $4001-5000 \mathrm{TL}$ & kişi & $\% 11$ \\
\hline $5000 \mathrm{TL}^{2} \mathrm{den}$ fazla & 14 kişi & $\% 17$ \\
\hline \multicolumn{3}{|c|}{ Ailede Parasal Kararları Veren } \\
\hline Siz & 10 kişi & $\% 12$ \\
\hline Siz ve Eşiniz & 46 kişi & $\% 55$ \\
\hline Eşiniz & 1 kişi & $\% 1$ \\
\hline Siz ve diğer bir aile üyesi & 26 kişi & $\% 32$ \\
\hline
\end{tabular}


Tablo 2: Finansal Ürünlerin(Araçların) Bilinirlilik Yüzdeleri

\begin{tabular}{|c|c|c|}
\hline Finansal Ürün(Araç) & Adet & $\%$ \\
\hline Kredi Kart1 & 81 kişi & $\% 98$ \\
\hline Yatrim Hesab1 & 59 kiși & $\% 71$ \\
\hline Vadesiz Mevduat Hesab1 & 64 kişi & $\% 77$ \\
\hline Hisse Senedi & 57 kişi & $\% 69$ \\
\hline Tahvil/Bono & 49 kişi & $\% 59$ \\
\hline Yatırım Fonu & 49 kişi & $\% 59$ \\
\hline Banka Kredisi & 70 kişi & $\% 84$ \\
\hline Emeklilik Fonları & 54 kişi & $\% 65$ \\
\hline Repo & 44 kiși & $\% 53$ \\
\hline Vadeli İslemler & 21 kişi & $\% 25$ \\
\hline Otomatik Ödeme Talimatı & 67 kişi & $\% 81$ \\
\hline Intemet Bankaciliğ1 & 66 kişi & $\% 80$ \\
\hline Telefon Bankaciliğ & 58 kişi & $\% 70$ \\
\hline ATM & 73 kişi & $\% 88$ \\
\hline Havale-EFT & 66 kişi & $\% 80$ \\
\hline
\end{tabular}

Katılımcıların finansal okuryazarlık düzeyini belirlemek amacıyla daha önce duymuş oldukları finansal ürünleri(araçları) işaretlemeleri istenmiştir. Tablo 2'de, finansal ürünlerin bilinirlilik yüzdeleri görülmektedir. Tablo 2, incelendiğinde katılımcılar ilk üç sırada en çok "Kredi Kartı", "ATM" ve "Banka Kredisi"ni bilirken en az oranda "Vadeli İşlemler" bilinmektedir.

Katılımcılara, daha önceki soruda kendilerine sorulan finansal ürünler(araçlar) den hangilerini kullandıkları (uyguladıkları) sorulmuştur. Alınan cevaplara göre katılımcılar ilk üç sırada en çok "Kredi Kartı" "ATM" ve "Havale-EFT" yi kullanırken, en az oranda "Vadeli İşlemler", "Tahvil/Bono" ile "Repo" araçlarını kullanmaktadır.

Tablo 3: Finansal Ürünleri(Araçları) Kullanma (Uygulama)Yüzdeleri

\begin{tabular}{|l|c|c|}
\hline Finansal Ürün(Araç) & Adet & $\%$ \\
\hline Kredi Kart1 & 77 kişi & $\% 93$ \\
\hline Yatırım Hesab1 & 22 kişi & $\% 27$ \\
\hline Vadesiz Mevduat Hesab1 & 49 kişi & $\% 59$ \\
\hline Hisse Senedi & 12 kişi & $\% 15$ \\
\hline Tahvil/Bono & $5 \mathrm{kişi}$ & $\% 6$ \\
\hline Yatırım Fonu & $10 \mathrm{kişi}$ & $\% 12$ \\
\hline Banka Kredisi & 43 kişi & $\% 52$ \\
\hline Emeklilik Fonlar1 & $16 \mathrm{kişi}$ & $\% 18$ \\
\hline Repo & $8 \mathrm{kişi}$ & $\% 9$ \\
\hline Vadeli İşlemler & 1 kişi & $\% 1$ \\
\hline Otomatik Ödeme Talimat1 & 48 kişi & $\% 58$ \\
\hline Intemet Bankacılığ1 & 49 kişi & $\% 59$ \\
\hline Telefon Bankacılığ1 & 34 kişi & $\% 41$ \\
\hline ATM & 69 kişi & $\% 83$ \\
\hline Havale-EFT & 58 kişi & $\% 70$ \\
\hline
\end{tabular}

Finansal ürünün (aracın) kullanılması yanında ne sıklıkta kullanıldığı, bir devamlılığının olup olmadığı da önemlidir. Tablo 4, katılımcıların son iki yıl içinde finansal ürünleri(araçları) kullanma sıklığına ilişkin yüzdeleri göstermektedir. 
Tablo 4: Finansal Ürünleri(Araçları) Kullanma Sıklığına İlişkin Yüzdeler

\begin{tabular}{|c|c|c|}
\hline Finansal Ürün(Araç) & Adet & $\%$ \\
\hline Kredi Kart1 & 73kişi & $\% 88$ \\
\hline Yatırım Hesabı & 18 kişi & $\% 22$ \\
\hline Vadesiz Mevduat Hesab1 & 42 kişi & $\% 51$ \\
\hline Hisse Senedi & 7 kişi & $\% 8$ \\
\hline Tahvil/Bono & 2 kişi & $\% 2$ \\
\hline Yatırım Fonu & 6 kişi & $\% 7$ \\
\hline Banka Kredisi & 39 kişi & $\% 47$ \\
\hline Emeklilik Fonları & 15 kişi & $\% 18$ \\
\hline Repo & 5 kişi & $\% 6$ \\
\hline Vadeli İşlemler & 1 kişi & $\% 1$ \\
\hline Otomatik Ödeme Talimat 1 & 39 kişi & $\% 47$ \\
\hline Intemet Bankacılığ1 & 42 kişi & $\% 51$ \\
\hline Telefon Bankacılığı & 29 kişi & $\% 35$ \\
\hline ATM & 66 kişi & $\% 80$ \\
\hline Havale-EFT & 49 kişi & $\% 59$ \\
\hline
\end{tabular}

Tablo 2, Tablo 3 ve Tablo 4 birlikte değerlendirildiğinde, katılımcıların belli bir bilgi birikimi gerektiren finansal araçlara ilişkin bilgilerinin olmadığı dolayısıyla bu araçlara ilişkin kullanım sıklıklarının düşük olduğu anlaşılmaktadır. Katılımcıların yatırım araçlarına kıyasla yoğun bir şekilde kredi kartını bildiği ve kullandığını bunun yanında ATM, Havale-EFT gibi araçları para yatırma ve para çekme gibi temel düzeydeki işlemleri gerçekleştirmek amacıyla kullandıkları söylenebilir.

Eğitim düzeylerine göre katılımcıların, finansal ürün seçiminde bulunurken farklı finansal kuruluşları karşılaştırmalarında bir farklılık olup olmadığını incelemek için ANOVA analizi yapılmıştır.

Tablo 5: İlköğretim Mezunu Olan Katılımcıların Finansal Ürün Seçimi Kararlarında Finansal Kuruluşları Karşılaştırması Farklılığı

\begin{tabular}{|l|c|c|c|l|c|}
\hline & $\begin{array}{l}\text { Kareler } \\
\text { Toplamı }\end{array}$ & $\begin{array}{l}\text { Serbestlik } \\
\text { Derecesi }\end{array}$ & $\begin{array}{l}\text { Ortalama } \\
\text { Kareler } \\
\text { Toplam1 }\end{array}$ & F & Anlamllık \\
\hline Gruplar & 8,692 & 1 & 8,692 & 9,501 &, 00 \\
Aras1 & & 81 &, 915 & & \\
\hline Gruplar İçi & 74,103 & 815 & & & \\
Toplam & 82,795 & 82 & & \\
\hline
\end{tabular}


Tablo 6: İlköğretim Mezunu Olan Katılımcıların Finansal Ürün Seçimi Kararlarında Finansal Kuruluşları Karşılaştırması Farklılı̆̆ı Tanımlayıcı İstatistikleri

\begin{tabular}{|l|c|c|c|}
\hline & $\begin{array}{l}\text { Gözlem } \\
\text { Say1s1 }\end{array}$ & Ortalama & $\begin{array}{l}\text { Standart } \\
\text { Sapma }\end{array}$ \\
\hline $\begin{array}{l}\text { İköğretim Mezuruı } \\
\text { Olmayanlar }\end{array}$ & 71 & 1,75 &, 81 \\
\hline $\begin{array}{l}\text { Ilköğretim Mezunu } \\
\text { Olanlar }\end{array}$ & 12 & 2,67 & 1,61 \\
\hline TOPLAM & 83 & 1,88 & 1,00 \\
\hline
\end{tabular}

Tablo 7: Üniversite Mezunu Olan Katılımcıların Finansal Ürün Seçimi Kararlarında Finansal Kuruluşları Karşılaştırması Farklılığı

\begin{tabular}{|l|c|c|c|c|c|}
\hline & $\begin{array}{l}\text { Kareler } \\
\text { Toplamı }\end{array}$ & $\begin{array}{l}\text { Serbestlik } \\
\text { Derecesi }\end{array}$ & $\begin{array}{l}\text { Ortalama } \\
\text { Kareler } \\
\text { Toplam1 }\end{array}$ & F & Anlamllik \\
\hline Gruplar & 6,332 & 1 & 6,332 & 6,708 &, 01 \\
Aras1 & & & & & \\
\hline Gruplar Iç̧i & 76,463 & 81 &, 944 & & \\
Toplam & 82,795 & 82 & & & \\
\hline
\end{tabular}

Tablo 8: Üniversite Mezunu Olan Katılımcıların Finansal Ürün Seçimi Kararlarında Finansal Kuruluşları Karşılaştırması Farklılı̆̆ı Tanımlayıcı İstatistikleri

\begin{tabular}{|l|c|c|c|}
\hline & $\begin{array}{l}\text { Gözlem } \\
\text { Say1s1 }\end{array}$ & Ortalama & $\begin{array}{l}\text { Standart } \\
\text { Sapma }\end{array}$ \\
\hline $\begin{array}{l}\text { Üniversite Mezunu } \\
\text { Olmayanlar }\end{array}$ & 45 & 2,13 & 1,14 \\
\hline $\begin{array}{l}\text { Üniversite Mezunu } \\
\text { Olanlar }\end{array}$ & 38 & 1,58 &, 72 \\
\hline TOPLAM & 83 & 1,88 & 1,00 \\
\hline
\end{tabular}

Tablo 5, Tablo 6, Tablo 7 ve Tablo 8 incelendiğinde ilköğretim mezunu olan katılımcıların diğer eğitim düzeyinde bulunan katılımcılara göre bir finansal ürün seçiminde bulunurken farklı finansal kuruluşları daha çok incelediği görülmektedir. Buna karşılık üniversite mezunu olan katılımcıların çok fazla karşılaştırma gereksinimi duymadıkları anlaşılmaktadır. Eğitim düzeyi arttıkça finansal araçlara ilişkin bilgi düzeyi artmaktadır. Özellikle finansal ürün karmaşıklaştıkça alternatifleri değerlendirme ve ihtiyaçları en iyi karşılayacak olanı bulma gereksinimi, eğitim düzeyi düşük olan bireyleri araştırmaya yöneltmektedir.

Katılımcıların bayan yada erkek olmasının hisse senedi yatırımlarının tahvil yatırımlarına kıyasla daha riskli olduğuna dair düşüncede bir farklılık yaratıp yaratmadığı incelenmiştir. Tablo 9 ve Tablo 10'da görüldüğü gibi bayan katılımcılar erkeklere göre hisse senetlerini tahvile göre daha riskli görmektedir. 
Tablo 9: Bayan yada Erkek Katılımcıların Hisse Senedi Yatırımlarının Tahvil Yatırımına Kıyasla Daha Riskli Olduğuna İlişkin Düşünce Farklılığı

\begin{tabular}{|l|c|c|c|c|c|}
\hline & $\begin{array}{l}\text { Kareler } \\
\text { Toplamı }\end{array}$ & $\begin{array}{l}\text { Serbestlik } \\
\text { Derecesi }\end{array}$ & $\begin{array}{l}\text { Ortalama } \\
\text { Kareler } \\
\text { Toplam1 }\end{array}$ & F & Anlamllık \\
\hline $\begin{array}{l}\text { Gruplar } \\
\text { Aras1 }\end{array}$ & 3,448 & 1 & 3,448 & 3,726 &, 05 \\
\hline $\begin{array}{l}\text { Gruplar Iç̧i } \\
\text { Toplam }\end{array}$ & 74,962 & 81 &, 925 & & \\
\hline
\end{tabular}

Tablo 10: Bayan yada Erkek Katılımcıların Hisse Senedi Yatırımlarının Tahvil Yatırımına Kıyasla Daha Riskli Olduğuna İlişkin Düşünce Farklılığı Tanımlayıcı İstatistikleri

\begin{tabular}{|l|c|c|c|}
\hline & $\begin{array}{l}\text { Gözlem } \\
\text { Sayısı }\end{array}$ & Ortalama & $\begin{array}{c}\text { Standart } \\
\text { Sapma }\end{array}$ \\
\hline Bayan Katılımcılar & 42 & 2,29 &, 94 \\
\hline Erkek Katılımcılar & 41 & 1,88 &, 98 \\
\hline TOPLAM & 83 & 2,08 &, 98 \\
\hline
\end{tabular}

Bayan katılımcıların yanında "18-25 yaş arası" katılımcılar olan en genç katılımcı grubu da hisse senedi yatırımlarını tahvile göre daha riskli bulmaktadır. Bayanlar ve gençlerin gelir düzeylerinin genellikle düşük ve kısıtlı olması nedeniyle finansal karar alırken risk unsuruna yoğunlaştıkları söylenebilir.

Tablo 11: “18-25 Yaş Arası” Katılımcıların Hisse Senedi Yatırımlarının Tahvil Yatırımına Kıyasla Daha Riskli Olduğuna İlişkin Düşünce Farklılı̆̆ı

\begin{tabular}{|l|c|c|c|c|c|}
\hline & $\begin{array}{l}\text { Kareler } \\
\text { Toplamı }\end{array}$ & $\begin{array}{l}\text { Serbestlik } \\
\text { Derecesi }\end{array}$ & $\begin{array}{l}\text { Ortalama } \\
\text { Kareler } \\
\text { Toplam1 }\end{array}$ & F & Anlamlılk \\
\hline Gruplar & 3,691 & 1 & 3,691 & 4,001 &, 04 \\
Aras1 & & 81 &, 922 & & \\
\hline Gruplar İci & 74,719 & 82 & & & \\
Toplam & 78,410 & 82 & & \\
\hline
\end{tabular}

Tablo 12: "18-25 Yaş Arası” Katılımcıların Hisse Senedi Yatırımlarının Tahvil Yatırımına Kıyasla Daha Riskli Olduğuna İlişkin Düşünce Farklılığı Tanımlayıcı İstatistikleri

\begin{tabular}{|l|c|c|c|}
\hline & $\begin{array}{l}\text { Gözlem } \\
\text { Say1s1 }\end{array}$ & Ortalama & $\begin{array}{l}\text { Standart } \\
\text { Sapma }\end{array}$ \\
\hline $\begin{array}{l}\text { "18-25 Yaş Arasi" Olan } \\
\text { Katıllımcilar }\end{array}$ & 15 & 2,53 & 1,06 \\
\hline $\begin{array}{l}\text { 18-25 Yaş Arasi" Olmayan } \\
\text { Katıllmmclar }\end{array}$ & 68 & 1,99 &, 94 \\
\hline TOPLAM & 83 & 2,08 &, 98 \\
\hline
\end{tabular}


Katılımcıların \%81'i "Yüksek enflasyon satın alma gücünün düşmesi demektir." ifadesinin doğru olduğunu belirtmişlerdir. Dolayısıyla katılımcılarda enflasyonu anlamak açısından temel düzeyde bir finansal okuryazarlık olduğu söylenebilir.

Tablo 13: Finansal Karar Almada Kullanılan Bilgi Kaynaklarına İlişkin Yüzdeler

\begin{tabular}{|c|c|c|}
\hline Bilgi Kaynakları & Adet & $\%$ \\
\hline Şubeden bilgi almak & 58 kişi & $\% 70$ \\
\hline Intemet kanaliyla bilgi almak & 49 kiși & $\% 59$ \\
\hline $\begin{array}{lcccc}\text { Ürün satış } & \text { sorumlusu } & \text { personel } & \text { tarafindan } \\
\text { bilgilendirilmek } & & & \\
\end{array}$ & 33 kişi & $\% 40$ \\
\hline $\begin{array}{l}\text { Gazete ve dergilerin finans-ekonomi sayfalarından } \\
\text { ögrenmek }\end{array}$ & 21 kişi & $\% 25$ \\
\hline Arac1 kurumlardan öğrenmek & 5 kişi & $\% 6$ \\
\hline Arkadaş çevresinden öğrenmek & 30 kişi & $\% 36$ \\
\hline Televizyon ya da radyo programından ögrenmek & 22 kişi & $\% 27$ \\
\hline Kendi bireysel deneyiminden faydalanmak & 26 kişi & $\% 31$ \\
\hline
\end{tabular}

Tablo 13'e göre katılımcılar en çok sırasıyla şubeden bilgi almak, internet kanalıyla ve ürün satış sorumlusu personel tarafindan bilgilendirilmeyi tercih etmektedirler. Özdemir (2012)'de yapmış olduğu çalışmada katılımcıların en çok tercih ettikleri bilgi edinme kaynaklarının bankalar, televizyon, internet ve devlet kuruluşları tarafından verilen eğitim seminerleri olduğunu belirlemiştir.

Katılımcıların basit faiz hesaplaması konusunda finansal okuryazar olup olmadıklarını belirlemek için "Bankada yatırım hesabınızda 1000 TL'niz var. Bankanın ödediği faiz oranı $\% 2$ ise 5 ay sonra yatırım hesabınızdaki paranız ne kadar olur?" şeklinde soru yöneltilmiştir. Tablo 14'te de görüldüğü gibi katılımcıların \%52'si “1020 TL'den daha fazla” seçeneğini işaretleyerek basit düzeyde bir faiz hesabına yorum yapabilmişlerdir. Eğitim düzeyi arttıkça soruya verilen doğru yanıtın arttığı gözlenmektedir.

Tablo 14: Faiz Hesaplamaya İlişkin Finansal Okuryazarlık Yüzdeleri

\begin{tabular}{|l|c|c|}
\hline & Adet & $\%$ \\
\hline 1020 TL'den daha fazla & 52 kişi & $\% 63$ \\
\hline 1020 TL & 17 kişi & $\% 20$ \\
\hline 1020 TL'den daha az & 14 kişi & $\% 17$ \\
\hline Toplam & $\mathbf{8 3}$ kiși & $\% 100$ \\
\hline
\end{tabular}

Katılımcıların gelişmiş finansal okuryazarlık düzeyinde olup olmadıklarını belirlemek amacıyla kendilerine "Eğer piyasa faiz oranı düşerse tahvil fiyatları bundan nasıl etkilenir?" sorusu yöneltilmiştir. Soruya "Bilemiyorum" yanıtını verenler \%52 olurken "Yükselir" doğru yanıtını verenler ise sadece \%16'dır. Dolayısıyla katılımcılar eğitim gerektiren konulardan birisi olan tahvil fiyatı piyasa faiz oranı ilişkisi konusunda bilgiye sahip olmadıkları anlaşılmaktadır.

Bilgi, emeklilik yatırımlarını teşvik etme gibi kamu politikaları, bireyin aileden edindiği olumlu çocukluk deneyimi, sosyal normlar ve tutumların hepsi hane halkının finansal 
yönetim davranışı üzerinde etkili bir rol oynar(Hilgert vd.,2003: 312). Hilgert, Hogarth ve Beverly (2003: 309-322)'in çalışmalarında olduğu gibi, bu çalışmada da hane halkı açısından finansal yönetim faaliyetleri, parasal akımların yönetimi, borçların yönetimi ile tasarruflar ve yatırımların yönetimi olmak üzere araştırılmıştır.

Devlet ve işletmelerin yaptığı gibi hane halkı da bütçeleme yaparak parasal açık ya da parasal fazlalıklarını tahmin etmelidirler. Parasal girişlerin parasal çıkışlardan fazla olması parasal fazlalık olarak tanımlanırken, parasal çıkışların parasal girişlerden fazla olması parasal açık olarak tanımlanır. Parasal akımların yönetilememesi işletmelerde iflasa kadar giden bir sürecin yaşanmasına neden olurken, hane halkının da parasal akımlarını yönetememesi ödeme güçlüğü yaşamalarına neden olacaktır. Yapılan çalışmada katılımcıların \%77'si “Bir bütçem diğer ifadeyle parasal harcamaya ilişkin planlamam var" ifadesini onaylarken, \%23'ü bir bütçesinin olmadığını belirtmiştir. Özdemir (2012: 29)'de yaptığı çalışmada katılımcıların \%78'inin bir finansal planı olduğunu belirlemiştir. Tablo 15 ve Tablo 16 incelendiğinde, bayan katılımcıların erkek katılımcılara kıyasla bütçe yapımına ilişkin ortalamalarının yüksek olduğu görülmektedir.

Tablo 15: Erkek yada Bayan Katılımcıların Bütçelerinin Olup Olması Açısından Farkl111k

\begin{tabular}{|l|c|c|c|c|c|}
\hline & $\begin{array}{l}\text { Kareler } \\
\text { Toplamı }\end{array}$ & $\begin{array}{l}\text { Serbestlik } \\
\text { Derecesi }\end{array}$ & $\begin{array}{l}\text { Ortalama } \\
\text { Kareler } \\
\text { Toplamı }\end{array}$ & F & Anlamlılık \\
\hline Gruplar & 3,577 & 1 & 3,577 & 5,076 &, 02 \\
Aras1 & & & & & \\
\hline Gruplar Iç̧i & 57,074 & 81 &, 705 & & \\
Toplam & 60,651 & 82 & & & \\
\hline
\end{tabular}

Tablo 16: Erkek yada Bayan Katılımcıların Bütçelerinin Olup Olması Açısından Farklılı̆̆ın Tanımlayıcı İstatistikleri

\begin{tabular}{|l|c|c|c|}
\hline & $\begin{array}{l}\text { Gözlem } \\
\text { Sayısı }\end{array}$ & Ortalama & $\begin{array}{l}\text { Standart } \\
\text { Sapma }\end{array}$ \\
\hline Erkek Katılımcılar & 41 & 1,56 &, 74 \\
\hline Bayan Katılımcilar & 42 & 1,98 &, 92 \\
\hline TOPLAM & 83 & 1,77 &, 86 \\
\hline
\end{tabular}

Bireyleri/hane halkını faturaları zamanında ödemeye teşvik etmek amacıyla finans eğiticileri genellikle onları bütçe yapmaya ve düzenli olarak mevcut harcamalarla planlanan harcamaları karşılaştırmaya teşvik ederler(O’Neill,2002: 53-58). Faturaları zamanında ödeyen bireylerin/hane halkının finansal plan(bütçe) yaptığı düşünülebilir. Çünkü finansal plan yaparken gelecek dönemde hane halkının ya da bireyin eline geçeceğini planladığı parasal girişler tahmin edilir. Aynı şekilde gelecek dönemde ödenmesi gereken parasal çıkışlar tahmin edilir. Bu süreci gözeten birey/hane halkı fatura ödemesini zaten plana dahil etmiştir ve bunu zamanında ödeyecektir. Yapılan çalışmada katılımcılar "Faturaları zamanında 
öderim" ifadesine \% 70 oranında kesinlikle katıldıklarını belirtmişlerdir. Bu oran finansal plan yapan katılımcılara yakın bir yüzdedir. Devaney ve diğerleri(1996: 76) yaptıkları çalışmada, faturalarını zamanında ödeyen katılımcıların yaşı arttıkça faturaların zamanında ödeme oranlarının arttığını belirlemişlerdir. Yapılan çalışmada da buna benzer sonuçlar ortaya çıkmıştır. "18-25 yaş” arası katılımcıların \%46'sı, “52 yaş ve üstü” katılımcıların ise \%84’ü faturalarını zamanında ödemektedir.

Tablo 17: Erkek yada Bayan Katılımcıların Kredi Kartı Kullanmaları Açısından Farkl1lık

\begin{tabular}{|l|c|c|c|l|c|}
\hline & $\begin{array}{l}\text { Kareler } \\
\text { Toplamı }\end{array}$ & $\begin{array}{l}\text { Serbestlik } \\
\text { Derecesi }\end{array}$ & $\begin{array}{l}\text { Ortalama } \\
\text { Kareler } \\
\text { Toplam1 }\end{array}$ & F & Anlamllik \\
\hline $\begin{array}{l}\text { Gruplar } \\
\text { Aras1 }\end{array}$ & 7,655 & 1 & 7,655 & 5,261 &, 02 \\
\hline Gruplar İçi & 117,863 & 81 & 1,455 & & \\
Toplam & 125,518 & 82 & & & \\
\hline
\end{tabular}

Tablo 18: Erkek yada Bayan Katılımcıların Kredi Kartı Kullanmaları Açısından Farklılı̆̆ın Tanımlayıcı İstatistikleri

\begin{tabular}{|l|c|c|c|}
\hline & $\begin{array}{l}\text { Gözlem } \\
\text { Say1s1 }\end{array}$ & Ortalama & $\begin{array}{c}\text { Standart } \\
\text { Sapma }\end{array}$ \\
\hline Erkek Katılımcilar & 41 & 1,49 &, 93 \\
\hline Bayan Katılımcilar & 42 & 2,10 & 1,43 \\
\hline TOPLAM & 83 & 1,80 & 1,24 \\
\hline
\end{tabular}

Yapılan çalışmada en düşük gelir düzeyi olan “1000 TL’den az” gelir düzeyinde olan katılımcıların kredi kartı kullanma oranı \%66 iken en yüksek gelir düzeyi olan "5000 TL'den fazla" gelir düzeyinde olan katılımcıların kredi kartı kullanma oranı \%86 olarak belirlenmiştir. Tablo 17 ve Tablo 18 incelendiğinde bayan katılımcıların kredi kartını erkek katılımcılara kıyasla daha fazla kullandıkları görülmektedir.

Katılımcıların \%75'i kredi kartı hesap özetlerini gözden geçirdiklerini ve \% 70’i her ay kredi kartımın dönem sonu borcunu ödediklerini belirtmişlerdir. Kredi kartı hesap özetlerinin kontrol edilmesi, kredi kartından mükerrer çekişlerin yapılıp yapılmadığının belirlenmesi, hesap hareketlerinin incelenerek kart sahibine ait olmayan harcamalar varsa bunların belirlenmesi açısından önemlidir. Eğer kredi kartı sahipleri, kredi kartı hesap özetinde belirtilen dönem sonu borcunun tamamını son ödeme tarihinde öderse fazladan komisyon ya da faiz ödemek zorunda kalmayacaklardır. Eğer son ödeme tarihinde borcun ödenememesi durumunda, ödenemeyerek kalan hesap bakiyesine asgari tutar ve üzerinde ödeme yapılması durumunda akdi faiz, asgari tutarın altında ödeme yapılması durumunda ise asgari tutarın ödenmeyen kısmına son ödeme tarihinden itibaren gecikme faizi uygulanır (Kaya, 2009:133). Bu bağlamda, kredi kartı kullanımı konusunda finansal okuryazar olmayan 
bir birey/hane halkı kredi kartının asgari tutarını ödemekle borcunu ödeyeceğini ya da ödediğini düşünebilirken aslında borcunun katlanarak büyüdüğünün farkında olmayabilir.

Bayan katılımcıların \%30’unun, erkek katılımciların \%39'unun bir yatırım hesabı bulunmaktadır. Gelir düzeyi arttıkça bireylerin yatırım yapma olanakları artmaktadır. "Gelir düzeyi 5000 TL'den fazla” olan katılımcıların \%71'inin yatırım hesabı olduğu belirlenmiştir.

Atkinson ve Messy(2012: 7)'nin yaptığı çalışma sonuçlarına göre, Tablo 19'da görüldüğü gibi Türkiye'de riski dağıtmakta çeşitlendirmenin faydasına ilişkin bilincin diğer ülkelerden yüksek olduğu belirlenmiştir. Bunun nedenlerinden birisi, Türkiye'de ekonomik istikrarın tam oturmaması, politik ve ekonomik risklerin yüksek olmasının bireylerde yüksek oranda çeşitlendirme farkındalığı yaratmış olduğu söylenebilir.

Tablo 19: Ülkelere Göre Bireylerin Çeşitlendirme Yapma Yüzdeleri

\begin{tabular}{|l|c|}
\hline Macaristan & $\% 61$ \\
\hline Estonya & $\% 57$ \\
\hline Almanya & $\% 60$ \\
\hline İrlanda & $\% 47$ \\
\hline Çek Cumhuriyeti & $\% 54$ \\
\hline İngiltere & $\% 55$ \\
\hline Malezya & $\% 43$ \\
\hline Polonya & $\% 55$ \\
\hline Ermenistan & $\% 59$ \\
\hline Türkiye & $\% 69$ \\
\hline Güney Afrika & $\% 48$ \\
\hline
\end{tabular}

Katılımcıların \%27'sinin bireysel emeklilik planı bulunmaktadır. Bu oran oldukça düşüktür. Bireysel emeklilik sistemi konusunda finansal okuryazarlığın tam olarak sağlanamadığı düşünülebilir. Bireysel emeklilik sistemi, emeklilik döneminde bireylere ek bir gelir sağlayarak refah seviyesini arttırmak amacıyla sosyal güvenlik sisteminin tamamlayıcısı olarak oluşturulmuştur. Emeklilik Gözetim Merkezi'nin 21 Kasım 2014 tarihli verilerine göre Türkiye genelinde Bireysel Emeklilik Sistemi'ne Kocaeli'nden katılanların oranı \%2,6'dır. Dolayısıyla gerek kitle iletişim araçlarıyla gerekse devlet ve sivil toplum kuruluşlarıyla birlikte bireysel emeklilik ürünleri tanıtılmalı, bireyler üzerinde bilinçlendirme ve eğitim ile farkındalık yaratılmalıdır. Katılımcıların \%8'i yatırım fonu kullanmaktadır. \%8'inin hisse senedi, \%6'sının tahvil/hazine bonosu yatırımı vardır. Merkezi Kayıt Kuruluşu'nun Borsa Trendleri Raporuna göre 2014 yılı eylül ayı itibariyle hisse senetlerine yatırım yapan yatırımcı sayısı 1.085.433 kişidir. Yatırım fonunda tasarruflarını değerlendiren kişi sayısı 2.697.272 kişi iken özel sektör tahvillerine 142.776 kişi, devlet iç borçlanma senetlerine ise 23.059 kişi yatırım yapmıştır. Bu veriler yapılan çalışmadaki katılımcıların eğilimlerle örtüşmektedir. Yatırımcılar, hisse senetlerini riskli bir yatırım aracı olarak görmekte, tahvil gibi uzun vadeli yatırım gerektiren ve faiz değişimine duyarlı yatırım araçlarına çok fazla yönelmemektedirler. Ancak sermaye piyasasının gelişimi için bireylerin tasarruflarını sermaye piyasasında 
değerlendirmesi gerekir. Dolayısıyla sermaye piyasalarının derinlik kazanabilmesi için bu alanda eğitim ve bilinçlendirme çalışmalarına yoğunlaşmak gerekmektedir.

\section{SONUÇ}

Yapılan çalışmada, katılımcıların finansal okuryazarlık açısından temel düzeyde bilgiye sahip oldukları ancak karmaşık ve bilgi bilmeyi gerektiren araç, ürün ve teknikler konusunda yetersizliklerin olduğu belirlenmiştir. Aynı zamanda hane halkı açısından yatırım araçlarını tanıma ve yatırım yapma konusunda bilgi eksikliğinin olduğu hisse senedi, tahvil, yatırım fonu gibi menkul değerlerin kullanımının düşük olduğu belirlenmiştir.

SPK, BIST ve ilgili kurumlar bir yandan halka arz seferberliği için bir yandan da finansal okuryazarlık düzeyinin artmasına yönelik faaliyetlerini sürdürerek sermaye piyasasının derinlik kazanmasına çalışmaktadırlar. Küçük tasarruflar büyük yatırımlara sermaye piyasaları aracılığıyla dönüşür. Türk Sermaye Piyasası'nın gelişebilmesi için yastık altında tutulan kaynakların finansal sisteme girişinin sağlanması gerekir. Bunun gerçekleşebilmesi için bireylerin finansal okuryazarlık düzeylerinin yükseltilmesi gerekir. $\mathrm{Bu}$ bağlamda finansal eğitim yolu ile farkındalık yaratılmalıdır.

Birey önce ailesinden sonra okul ve toplumdan edindiği finansal eğitim ve deneyimleriyle hareket eder. Hane halkının bir aile bütçesinin olup olmadığı, borçların yönetimi ile tasarruflar ve yatırımların yönetimi konusunda sahip olunan bilgi düzeyi, tutum ve davranışlar finansal okuryazarlık konusunun değerlendirilmesinde kullanılması gereken tamamlayıcı verilerdir. Bu çalışmada, hane halkının bir finansal planının diğer ifadeyle bir bütçesinin olduğu, büyük bir çoğunluğunun faturaları zamanında ödedikleri, kredi kartı hesap özetlerini kontrol ettikleri belirlenmiştir. Ancak yatırım konusunda özellikle bir emeklilik yatırımlarının olmaması dikkat çeken noktalar arasındadır. Bireysel emeklilik sistemi ile Türkiye'de sisteme katılma oranları giderek yükselmesine rağmen bu rakamlar hala arzu edilen düzeyde değildir. Bu bağlamda, finansal eğitim ve finansal okuryazarlı̆̆ın sadece bu alanda üniversitelerde eğitim alan kişilerin değil tüm toplumu oluşturan bireylerin en azından kendi finansal güvenliğini sağlayacak düzeyde eğitime tabi tutulması gerektiği söylenebilir. "Finansal Erişim, Finansal Eğitim, Finansal Tüketicinin Korunması Stratejisi ve Eylem Planları" 5 Haziran 2014 tarihli ve 29021 sayılı resmi gazetede yayınlanmıştır. Hazırlanan finansal eylem planında detaylı çalışmalar öngörülmektedir. Bunlardan bazıları: Finansal eğitimle ilgili doküman ve çalışmalara yönelik bir internet sayfası oluşturulması, finansal eğitim faaliyetlerinin sosyal medya yolu ile duyurulması, finansal ürün ve hizmetlerin, finansal piyasalardaki risklerin anlaşılmasına, bilinçli tercihler yapılmasına ve yardım başvurusu prosedürlerine ilişkin açıklayıcı broşür, kitapçık, eğitici oyunlar ve benzeri kaynakların yaygınlaştırılması, ev hanımlarının finansal konularda bilinçlendirilmesi, ilk ve orta öğretim düzeyinde müfredattaki ve yaygın eğitim programlarındaki temel finans konularının geliştirilmesi, yükseköğretim düzeyinde finans ile ilgili programların ders 
içeriklerinin gözden geçirilmesi ve finans dışı programlarda da finansal eğitimin verilmesi yapılması planlanan çalışmalar arasında yer almaktadır.

\section{KAYNAKLAR}

Araz, Tülin (2012), Financial Literacy and Credit Card Arrears, Boğaziçi Üniversitesi Sosyal Bilimler Enstitüsü, Yüksek Lisans Tezi, İstanbul.

Atkinson, Adele. - Messy, Flore Anne. (2012), Measuring Financial Literacy: Results of the OECD / International Network on Financial Education (INFE) Pilot Study, OECD Working Papers on Finance, Insurance and Private Pensions, No 15, OECD Publishing.

Bayram, Seliha Seçil (2010), Finansal Okuryazarlık ve Para Yönetimi Davranışları: Anadolu Üniversitesi Öğrencileri Üzerine Bir Araştırma, Anadolu Üniversitesi Sosyal Bilimler Enstitüsü, Yüksek Lisans Tezi, Eskişehir.

Devaney, Sharon.- Gorham, Elizabeth.-Bechman, Janet.- Haldeman, Virginia. (1996), "Cash Flow Management and Credit Use: Effect of a Financial Information Program”, Association for Financial Counseling, Planning, Budgeting, Vol 78, pp.71-80.

Hilgert, Marienne.- Hogarth, Jeanne.- Beverly, Sondra (2003); "Household Financial Management. The Connection between Knowledge and Behavior”, Federal Reserve Bulletin, Vol 87, pp.309-322.

Kaya, Ferudun (2009), Türkiye'de Kredi Kartı Uygulaması, Türkiye Bankalar Birliği Yayını, No 263.

Lusardi, Annamaria (2008), “Financial Literacy: An Essential Tool for Informed Consumer Choice?”, NBER Working Paper Series, Working Paper. 14084, June, pp.1-30.

Mason, Carolynne - Wilson, Richard. (2000), Conseptualising Financial Literacy, Loughborough University, Business School Research Series, London.

Moore, Danna (2003), Survey of Financial Literacy in Washington State: Knowledge, Behavior, Attitudes, and Experiences, Technical Report N. 03-39, Social and Economic Sciences Research Center, Washington State University.

National Council for Economic Education (NCEE) (2005), What American teens \& adults know about economics.

(http://www.ncee.net/cel/WhatAmericansKnowAboutEconomics_042605-3.pdf, 01.12.2014)

OECD (2005), Improving Financial Literacy: Analysis of Issues and Policies.

O’Neill, Barbara (2002), “Twelve Key Components of Financial Wellness”, Journal of Family and Consumer Sciences, Vol 94, No 4, pp.53-58, aktaran Hilgert, Marienne.Hogarth, Jeanne.- Beverly, Sondra (2003); "Household Financial Management. The Connection between Knowledge and Behavior”, Federal Reserve Bulletin, Vol 87, p.312. 
Özdemir, Kamer Karakum (2012), Türkiye Finansal Yeterlilik Araştırması Ön Sonuçları, Dünya Bankası, TÜSİAD Finansal Okuryazarlık Konferansı.

(http://siteresources.worldbank.org/TURKEYINTURKISHEXTN/Resources/Finansal_Yeterli lik_Anket_sonuclari.pdf, 15.10.2014)

President's Advisory Council On Financial Literacy, 2008 Annual Report to the President, United States of America.

Sermaye Piyasası Kurulu (2014), Finansal Erişim, Finansal Eğitim, Finansal Tüketicinin Korunması Stratejisi ve Eylem Planları,

(http://www.spk.gov.tr/displayfile.aspx?action=displayfile\&pageid=1076\&ext=pdf, 13.03.2015)

T.C. Merkez Bankası (2011), Dünyada ve Türkiye'de Finansal Hizmetlere Erişim ve Finansal Eğitim, Ankara.

Temizel, Fatih - Bayram, Fatih (2011), "Finansal Okuryazarlık: Anadolu Üniversitesi İktisadi ve İdari Bilimler Fakültesi (İ̈BF) Öğrencilerine Yönelik Bir Araştırma", Cumhuriyet Üniversitesi İktisadi ve İdari Bilimler Dergisi, Cilt 12, Sayı 1, ss.73-86.

Volpe, Ronald.- Chen, Haiyang.- Pavlicko, Joseph. (1996), "Personal investment literacy among college students: A survey”, Financial Practice and Education, Vol 6, pp.86-94.

Volpe, Ronald.- Kotel, Joseph.- Chen, Haiyang. (2002), "A survey of investment literacy among online investors”, Financial Counseling and Planning, Vol 13, Issue 1, pp.1-16. 
